Институт педагогики, психологии и социальных проблем

А.Р. Камалеева, Л.А. Шибанкова, А.С. Кац

\title{
СИСТЕМЫ ОБРАЗОВАНИЯ В РОССИИ И ЗА РУБЕЖОМ
}

\section{Научно-методическое пособие}

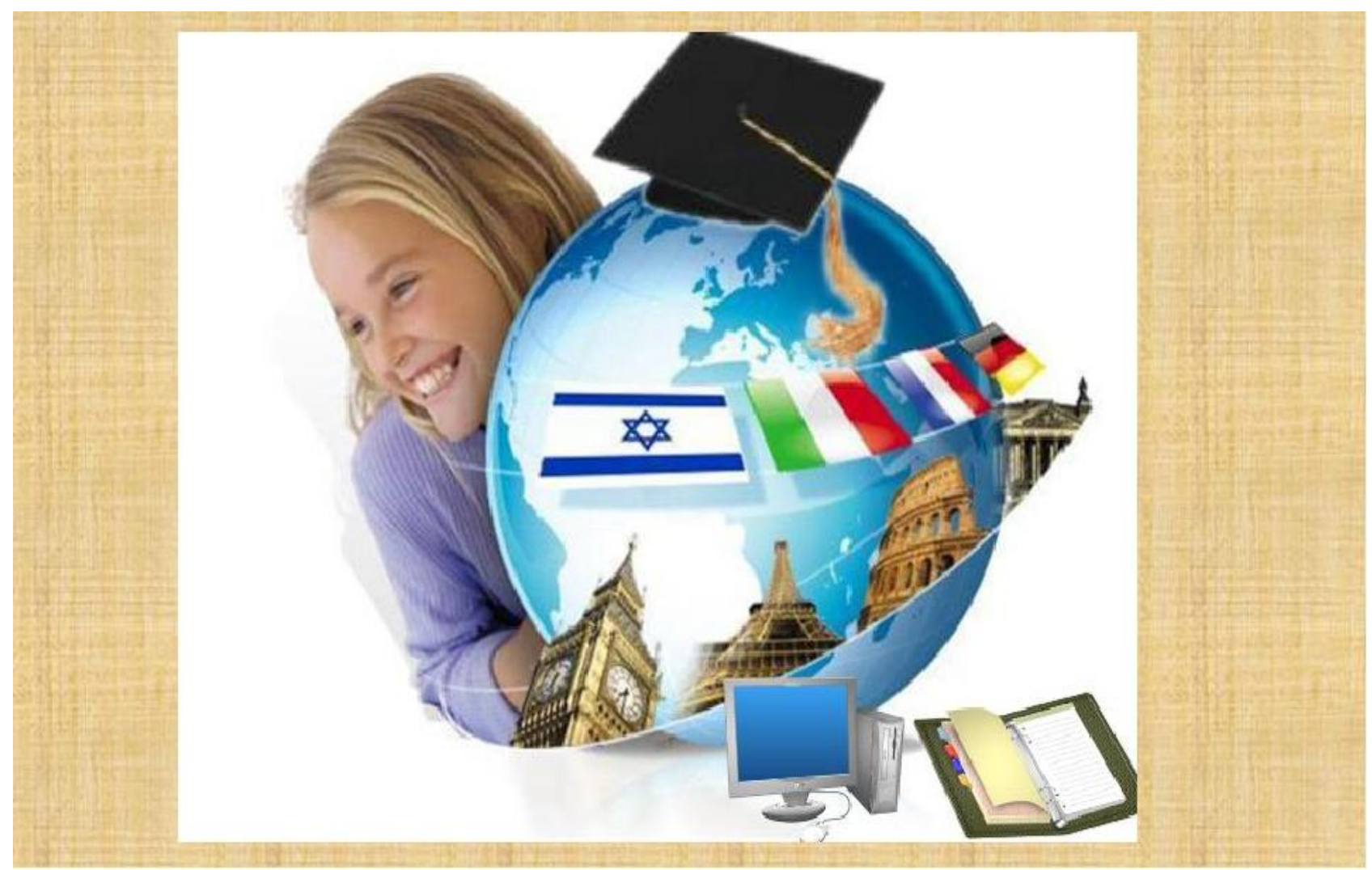

Казань - 2021 
УДК 371/378

ББК 74.2/74.4

C34

Утверждено Ученым Советом ФГБНУ «Институт педагогики, психологии и социальных проблем»

Рецензенты:

Мусалимова Альфия Рафисовна - доктор педагогических наук, доцент

Стукалова Ольга Вадимовна - доктор педагогических наук, доцент

C34 Системы образования в России и за рубежом: научно-методическое пособие / А.P. Камалеева, А.С. Кац, Л.А. Шибанкова. - Казань: Институт педагогики, психологии и социальных проблем, 2021. - 386 с.

\section{DOI: 10.51379/j2541-1538-1199-g ISBN 978-5-89917-257-1}

В научно-методическом пособии раскрывается педагогический потенциал систем образования России и зарубежных стран в эпоху цифровизации. Представлена картина развития образования с различных позиций, начиная с раскрытия общих трендов развития современного образования, модернизации обучения и воспитания в мировом образовательном пространстве, путей развития школьного образования и заканчивая изучением роли школьного учителя в современной образовательной системе. В пособии описывается и презентуется опыт Европейских и скандинавских стран, США и Японии.

Материалы могут быть полезны педагогам, психологам, преподавателям высшей школы; студентам и аспирантам педагогических специальностей, а также всем, кто интересуется теоретическими и практическими вопросами развития образования в современном мире.

\section{ISBN 978-5-89917-257-1}

СИППСП, 2021

(C) Коллектив авторов 


\section{СОДЕРЖАНИЕ}

Введение..............................................................

1. Тренды развития современного образования (Л.А. Шибанкова)

2. Высшее образование в Российской Федерации: нормативы, тренды, ценности (А.С. Кац)......................................

3. Модернизация обучения и воспитания (А.Р. Камалеева)......... 31

4. Пути развития школьного образования (А.Р. Камалеева).......

5. Школьный учитель за рубежом (А.Р. Камалеева).

6. Система образования США (А.Р. Камалеева)..................... 83

7. Высшая школа стран Скандинавии (А.Р. Камалеева)........... 93

Приложения........................................................... 99

Презентация 1........................................................ 100

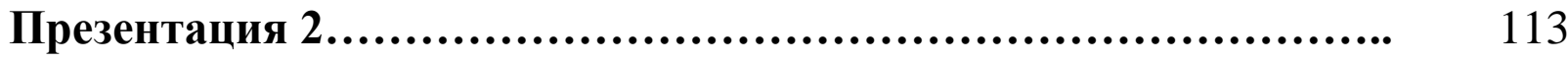

Презентация 3...................................................... 131

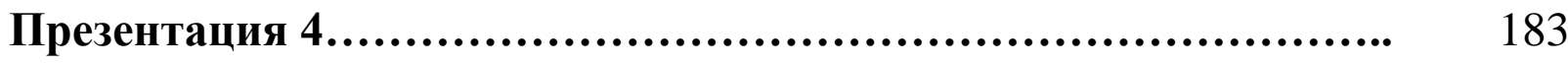

Презентация 5................................................... 234

Презентация 6...................................................... 313

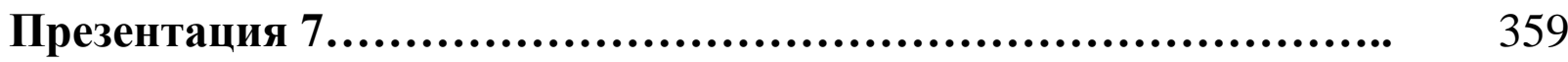

